DOI: $10.14451 / 2.127 .7$

\title{
К ВОПРОСУ О ДОВЕРИИ В ПРАВЕ
}

\author{
(C) 2019 Тихонова Жанна Курбановна \\ аспирант \\ Самарский государственный экономический университет \\ 443090, г. Самара, ул. Советской Армии, д. 141 \\ E-mail:pravo.63@list.ru
}

Данная статья посвящена изучению понятия и признаков доверия с правовой точки зрения. Интерес к доверию, как к правовой категории, возник не так давно, поэтому данный феномен малоизучен в этом смысле. В основном работы посвящены изучению способов повышения доверия к праву и государству, соотношения таких понятий как доверие и недоверие, вопросам доверия к правосудию. Между тем, по нашему мнению, категория «доверие» является одной из важных в теории государства и права, соответственно, однобокий подход к ее изучению может оставить пробелы, что не позволит в дальнейшем прикладным юридическим наукам решить те задачи, в которых присутствует так или иначе доверие.

В статье исследуется интерпретация доверия с правовой точки зрения, рассматриваются определения, данные в различных науках: в философии, социологии, психологии. Доверие содержится, очевидно, имплицитно во многих правовых явлениях, некоторые из которых отражены в настоящей работе. Для отличия доверия как правовой категории от аналогичной категории в других науках выявлены его признаки, присущие именно доверию в праве, что говорит о новизне научного исследования.

Ключевые слова: доверие, признаки доверия, доверие как элемент правосознания, место доверия в праве.

В последнее время наряду с исследованием фундаментальных понятий, явлений юриспруденции особый интерес ученых вызывают феномены, которые больше связаны с психологией, социологией, нежели с правовыми науками. Тем не менее, они тесно вплетаются в право, влияют на него, изменяют, дополняют. Одним из таких феноменов является доверие. На первый взгляд, явление не правовое, но, изучая сущность права, вопросы становления государства, основания правоотношений, мы так или иначе сталкиваемся с тем, что доверие имманентно содержится в них, в связи с чем представляется необходимым изучение феномена доверие под углом зрения права, а не психологии или социологии.

В философии можно встретить раскрытие феномена доверие в теориях происхождения государства (Аристотель, Н. Макиавелли, Т. Гоббс, Дж. Локк, Г. Гроций, Ж.-Ж. Руссо). Одни считали доверие как необходимое условие существования государства, другие, напротив, считали это возможным, но необязательным условием, ибо «люди меньше остерегаются обидеть того, кто внушает им любовь, нежели того, кто внушает им страх, ибо любовь поддерживается благо- дарностью, которой люди, будучи дурны, могут пренебречь ради своей выгоды, тогда как страх поддерживается угрозой наказания, которой пренебречь невозможно» [1]. То есть если выбирать между доверием и страхом как основой государства, то более надежным, по мнению Н. Макиавелли, будет страх.

В психологии под доверием понимают эмоциональную установку, оптимистичное отношение к объекту [2], психологическое отношение, состоящее из эмоционального, когнитивного, поведенческого элементов [3].

В социологии встречаются два основных подхода к пониманию доверия: рациональный (основанный на расчетах, на прошлом опыте) и иррациональный (основанный на чувствах, внутренних убеждениях).

Так, М. Вебер, Дюркгейм считали, что доверие - характеристика межличностного общения. Современные же социологи (Н. Луман, Э. Гидденс, Дж. Коулмен,) определяют доверие как символический кредит, способ накопления социального капитала, под которым понимается потенциал взаимного доверия и взаимопомощи в виде социальных норм и правил, формирую- 
щих ожидания и обязательства.

Среди правоведов следует выделить точку зрения Кокотова А.Н., который считает что доверие - социально-психологическое явление, задаваемое всей правовой системой, а также мнение Арапова Н.А., согласно которому доверие - ожидание граждан, сопряженное с определенными рисками [4; 7].

Однако данные определения доверия в праве являются ограниченными, размытыми, не затрагивающими всех областей системы права.

В связи с этим необходимо выявить признаки доверия как правовой категории и определить его место в правовой системе.

Наш современный мир - это уже не средневековые государства, где царствуют насилие, принуждение, беззаконие. Все-таки большинство стран являются правовыми, где выборные государственные органы, глава государства. И для мирного и благополучного существования и развития такого государства необходимо общественное доверие, которое бы постоянно поддерживалось государством.

Следует согласиться с мнением [5], что источник такого доверия, прежде всего, в правосознании людей, которое формируется в повседневной жизни: при осуществлении своих прав, исполнении обязанностей. Насколько защищенным чувствует при этом себя человек, настолько у него развито чувство доверия к государству. Все это реализуется посредством государственного механизма. Насколько органы государственной власти приближены к проблемам народа и занимаются их разрешением, настолько народ оказывает им доверие. Абсолютно обоснованно отметил Л. Москвин, что доверие к власти - это результат ее деятельности [6]. В связи с этим государству необходимо постоянно держать на контроле вопрос доверия к нему граждан. Не зря некоторые ученые выделяют поддержание государством такого доверия в качестве одного из принципов конституционного права [7, С. 157-173], что говорит о его важности для функционирования государства в целом.

Помимо личного опыта, есть и внешние факторы, оказывающие влияние на правосознание индивида. К ним относятся средства массовой информации, интернет, а также опыт других лиц. К сожалению, в СМИ чаще можно услышать о плохой работе какого-либо органа государственной власти, о каких-то ошибках отдельного сотрудника такого органа, либо непристойном поведении кого-либо из чиновников, нежели об их хорошей работе. Газета с заголовком, например, о том, что у депутата нашли дома 5 млрд. долларов, будет иметь большую популярность, чем газета с заголовком о том, что Правительство выделило денежные средства на строительство школ. Новость будет интересной, если в ней будет кто-то очернен, разоблачен, нежели сообщение о том, какая каждодневная работа была проделана тем или иным ведомством - это не новость, это неинтересно. Согласимся с мнением некоторых авторов, что зачастую СМИ плохо влияет на правосознание людей [8]. Следовательно, необходимо простимулировать теле-, радиовещание, интернет на публикацию в большей степени положительных новостей для формирования позитивного правосознания у граждан, т.е. для повышения доверия у общества.

Показатель правосознания граждан четко прослеживается в избирательном праве, когда граждане при осуществлении своих прав руководствуются доверием к тому или иному кандидату на выборную должность, политической партии, оказывают доверие (либо недоверие) к членам избирательной комиссии. Отдав голос конкретному кандидату, гражданин проявляет доверие, что проводимая этим кандидатом политика будет соответствовать заявленной программе, что его права не будут нарушаться, что этот человек оправдает его ожидания в политическом смысле. При выборах президента гражданин доверяет кандидату, за которого он голосует, руководство страны. При этом зачастую при последующих выборах гражданин не оказывает того доверия, которое было ранее к определенному кандидату, может появиться другой, более достойный, по мнению гражданина, кандидат. Таким образом, стабильности в данном вопросе нет. Для того, чтобы получить доверие граждан, как говорилось выше, нужно не только декларативно заявлять «о лучшей жизни», но и делами укреплять оказанное доверие.

В гражданском праве доверие присутствует при заключении сделок. Совершая сделку, сторона тем самым проявляет к контрагенту доверие, что сделка будет исполнена на оговоренных условиях. При этом проверку контрагента на добросовестность нельзя считать недоверием, это обычное нормальное поведение субъекта правоотношений, поскольку какие-либо проверки не исключают недобросовестность стороны сделки на 100 процентов, а лишь выявляют очевидные 
обстоятельства, свидетельствующие о наличии риска.

Особый интерес при рассмотрении вопроса о доверии представляют действующие в процессуальном праве презумпции (невиновности, правомерности сделки, отцовства и т.д.) и преюдиция. При разрешении семейных споров, например, об установлении размера алиментов, суд проявляет доверие истцу, что отцом ребенка является указанное в иске лицо, при этом данный факт не проверяется. Проявление доверия, на наш взгляд, должно в чем-то выражаться. В данном случае суд устанавливает при наличии других оснований размер алиментов, которые обязан выплачивать ответчик. При взыскании задолженности суд проявляет доверие стороне, что сделка, на которой основывает свои требования кредитор, правомерна, и взыскивает при наличии оснований сумму долга.

Презумпции также являются формой выражения доверия. Суд не проверяет факты, установленные другим судом, по делам с участием этих же лиц, то есть он доверяет другому суду, что выводы, сделанные в рамках рассмотрения иного дела, верны. На основании презумпций, с их учетом суд выносит соответствующее решение.

Таким образом, мы видим, что доверие в праве всегда сопровождается определенными действиями, это не просто эмоциональная уста- новка какого-либо субъекта, это не характеристика межличностного общения. Это и отличает доверие в праве от доверия в психологии и социологии. Доверие как чувство, не имеющее внешнего выражения в каких-либо правоотношениях, не правовая категория. Доверие же, которое проявляется в тех или иных правоотношениях, является безусловно категорией правовой.

Помимо этого, следует обратить внимание на субъектно-объектный состав, который также характеризует исследуемый феномен как правовую категорию. Как субъектом, так и объектом доверия может выступать помимо человека, государство, государственные органы. Естественно, что их представляют люди. Но они осуществляют свою деятельность от имени государства, в этом и специфика правовой категории доверия, в ее абстракции.

На основании вышеизложенного можно выделить следующие признаки доверия как правовой категории: зависимость от объекта, которому оказывается доверие, нестабильность, алеаторность, прогностичность, избирательность, верифицируемость, специальный субъектный состав, выражение в действиях.

Таким образом, выделенные признаки характеризуют доверие как правовую категорию, являются отличными от иных категорий доверия.

\section{Библиографический список}

1. Макиавелли Н. Избранные произведения. Москва.1982

2. Jones K. Trust as an affective attitude// Ethics. 1996. № 107. p.4-25

3. Купрейченко А.Б. Психология доверия и недоверия. Москва. 2008. 571 с.

4. окотов А.Н. Доверие. Недоверие. Право. Москва. 2004. 192 с.

5. Пантыкина М.И. Доверие в праве как когнитивная установка индивидуального правосознания // Философия права. 2016, № 2. С. -54

6. Москвин Л. Власть и общество: проблема доверия // Власть. 2011, № 9. С. 7-10

7. Арапов Н.А. Принцип поддержания доверия граждан к закону и действиям государства в российском конституционном праве и правосудии. Автореф. дисс. на соиск. уч. степ.к.ю.н. Санкт-Петербург, 2015

8. Савкина М.А. Доверие граждан к правосудию: состояние и перспективы // Вестник Нижегородского университета им. Н.И. Лобачевского. 2013, № 6. С. 317-320

9. Вебер М. Избранные произведения. Москва. 1990. 808 с.

10. Гидденс Э. Последствия современности. Москва. 2011. 343 с.

11. Дюркгейм Э. О разделении общественного труда. Метод социологии. Москва. 1991. 576 с.

12. Луман Н. Социальные системы. Очерк общей теории. Санкт-Петербург. 2007. 643 с.

13. Селигмен А. Проблема доверия. Москва. 2002. 256 с. 